\title{
THE CONCEPT OF DEVELOPMENT OF INNOVATION ACTIVITY OF THE REGIONAL ECONOMIC SYSTEMS
}

An unexplored point in the study of economic systems is the transition of their activities to an innovative path of development. Therefore, in our opinion, it is important to consider various aspects of transformation that can create the preconditions for innovation in order to overcome the trajectory of economic systems, a special direction that can solve pressing problems and take into account regional features of their economic activity. The theoretical and methodological basis of the study are scientific approaches, principles and concepts presented in the works of foreign and domestic scientists on the development of innovation in regional economic systems. For the analysis and systematization of theoretical and practical material the methods of the system approach in its subject-object and functional-structural aspects were used; program-oriented, problem-oriented approaches; methods of formalization and modeling. The article reveals the essence of the concept of development of innovative activity of regional economic systems. When studying the issues of innovation of regional economic systems, internal and external factors of renewal were identified, as well as the objective conditions of their functioning were substantiated. The main directions and rates of development of features of economic systems for the purpose of qualitative transformation and increase of the basic economic indicators are defined. A conceptual scheme for assessing the prospects and potential effectiveness of the transformation period within the region is proposed. The paper presents a number of auxiliary algorithms de-veloped by the author, which ultimately relate to the identification of strategic advantages of a particular area of the region and help to rationally change for the better the preliminary assessment of the transformation of the economic system of the region. It is determined that the concept of development of innovative activity of the economic system can be defined as the economic growth of the economic entity on the basis of development and implementation of new or improvement of existing technologies. The level of innovative development is determined both by the resource component of the innovation process (innovation potential) and the efficiency of the transfer of innovative technologies.

Key words: innovations, innovative activity, economic system, regional de-velopment, concept, transformation.

DOI: https://doi.org/10.32838/2523-4803/70-3-37

УДК 338.244.47:338.48

\section{Мілінчук О.B.}

кандидат економічних наук, доцент,

Державний університет «Житомирська політехніка»

\author{
Milinchuk Olga \\ Zhytomyr Polytechnic State University
}

\section{РОЗВИТОК СІЛЬСЬКОГО ТУРИЗМУ В УМОВАХ ДЕЦЕНТРАЛІЗАЦІї: ДОСВІД ЖИТОМИРЩИНИ}

\begin{abstract}
У статті розглянуто сутність сільського туризму, визначено законодавчі особливості організаиії сільського туризму в межах об'єднаних територіальних громад. Узагальнено вплив сільського туризму на розвиток об'єднаної територіальної громади в умовах децентралізації. Проаналізовано статистичні дані стану розвитку сільського туризму в розрізі регіонів та України у цілому. Досліджено Житомирщчину як окремий регіон для розвитку сільського туризму, перераховано послуги сільських садиб області. Визначено державні структури, які сприяють розвитку туризму на регіональному рівні. Проведено SWOT-аналіз сільського туризму Житомирщини та визначено стратегічні иілі розвитку. Узагальнено перелік зацікавлених сторін у розвитку сільського туризму та визначено вплив їх співпраці на розвиток сільського туризму Житомирщини.

Ключові слова: сільський туризм, сільська садиба, дещентралізачія, об 'єднана територіальна громада, сільський туризм Житомирщиини.
\end{abstract}

Постановка проблеми. Державна політика України у сфері місцевого самоврядування спирається на інтереси жителів територіальних громад і передбачає децентралізацію влади, тобто передачу від органів виконавчої влади органам місцевого самоврядування значної частини повноважень, ресурсів та відповідальності. Оскільки в результаті децентралізації влади основою нової системи місцевого самоврядування $€$ 
об'єднані територіальні громади (ОТГ), то і значна частина повноважень, у тому числі у сфері туризму, має бути передана міським, селищним та сільським ОТГ, де такі повноваження можна реалізовувати найбільш успішно.

Забезпечення прискореного розвитку сфери туризму в умовах децентралізації та розширення повноважень місцевих органів влади сприятиме комплексному розвитку територій, зокрема створенню сприятливих умов для залучення інвестицій у розбудову туристичної інфраструктури, формуванню позитивного туристичного іміджу окремих регіонів. Особливо актуальним є дослідження успішних практик сільського туризму в межах новоутворених об'єднаних територіальних громад.

Аналіз останніх досліджень і публікацій. Питанням діяльності органів державного управління у сфері туризму присвячено низку праць вітчизняних науковців, серед яких можна назвати публікації В. Бирковича [1], А. Голикова, Н. Казакова [2], А. Голод, О. Коркуна [3], Н. Гончарук, Г. Колєди [4], С. Захарової [7], Л. Івашиної [8], М. Ільїної, І. Шпильового [9], М. Костриці [15], Л. Матвійчук, I. Тищук [16] та ін. Зокрема, М. Ільїна та I. Шпильовий підкреслюють, що «...3 1990-х років із застарілого галузевого підходу, який трактував сільські території винятково як просторову базу для агровиробництва, перейшли до концепції ïx багатофункціонального розвитку. За цією концепцією сільські території мають отримати додатковий поштовх для розвитку за рахунок розміщення промислових підприємств та виробництва послуг, у т. ч. туристично-рекреаційних» [9, с. 447]. У дослідженнях Н. Гончарук та Г. Колєди з посиланнями на положення Закону України «Про місцеве самоврядування в Україні» [20] обгрунтовано можливість створення ефективної системи управління сферою туризму на регіональному та місцевому рівнях в умовах децентралізації влади в Україні [4, с. 99-100]. Проте у цілому питання особливостей державного управління сферою туризму в науковій літературі досліджено фрагментарно, особливо це стосується питань розвитку сільського туризму на регіональному рівні в умовах децентралізації влади в Україні.

Формулювання цілей статті. Метою дослідження $\epsilon$ вивчення особливостей розвитку сільського туризму в умовах децентралізації влади на прикладі Житомирської області.

Виклад основного матеріалу. Сільські теритоpiї України перебувають в складному становищі. За даними Державного комітету статистики, з 1995 р. до початку 2020 р. Україна втратила 488 сільських населених пунктів та 26 селищ міського типу, їхні назви зникли із сучасних географічних мап [18]. Нині в Україні залишилося 28376 сіл та 883 селища міського типу [18]. Ця тенденція є негативною, оскільки більшість мешканців, які проживають у селах, є осередками збереження культурної спадщини держави та мають екологічно чисті зони для відпочинку туристів, не маючи стабільних доходів, змушені виїжджати в міста або й за межі країни з метою пошуку кращих умов життя та отримання достойного заробітку. Проте зменшення кількості українських сіл та міграцію населення можна зупинити завдяки сприянню ефективному функціонуванню на їхніх територіях підприємницьких ініціатив, у тому числі з розвитку сільського туризму.

В Україні відсутнє законодавче врегулювання питань ведення сільського туризму, зокрема в 2003 р. зареєстровано, проте не прийнято Верховною Радою IV скликання проєкт закону «Про сільський та сільський зелений туризм» [21]. Згідно з даним законодавчим актом:

- сільській туризм - це відпочинковий вид туризму, що передбачає тимчасове перебування туристів у сільській місцевості (селі);

- сільській зелений туризм - це відпочинковий від сільського туризму, пов'язаний із перебуванням туристів у власному житловому будинку сільського господаря, окремому (гостевому) будинку або на території особистого селянського (фермерського) господарства [21, Р. 1 ст. 1$]$.

Згідно 3 альтернативним проєктом закону «Про аграрний туризм та агротуристичну діяльність» [22], також визначено низку термінів, зокрема:

- сільська садиба - це розташований у сільській місцевості та пропонований для тимчасового розміщення туристів житловий будинок із присадибною земельною ділянкою, що є майном особистого селянського господарства.

Фактично сільський туризм у громадах був унормованим лише в Законі України «Про особисте селянське господарство» від 2003 р. як вид непідприємницької діяльності, зокрема ст. 1 Закону визначає особисте селянське господарство (ОСГ) як господарську діяльність, окрім іншого, з надання послуг із використанням майна цього господарства, у тому числі й у сфері сільського туризму [5]. Отже, послуги у сфері сільського туризму не обкладаються податком, фізичні особи власники ОСГ, які працюють у цій сфері, оподатковуються податком із доходів фізичних осіб, вони є також платниками земельного податку. Постановою КМУ від 2006 р. № 297 «Про затвердження порядку надання послуг із тимчасового розміщення (проживання)» п. 2 регламентовано, що індивідуальне розміщення 3 оплатою або без оплати обмежується кількістю місць (менше 30), одиниці розміщення (кімнати) повинні бути відокремлені одна від одної; у п. 7 цієї Постанови вказано, що фізичні особи - власники засобів розміщення надають послуги з тимчасового проживання без державної реєстрації їх як суб'єктів підприємницької діяльності [19]. Як наслідок, законодавчо правильним під час надання послуг сільського туризму фіксувати їх як послуги проживання. Варто зазначити, що статистичні дані збираються на основі Звіту про діяльність колективного засобу розміщення (Форма № 1-КЗР (річна), затверджена Наказом Держстату України від 30.11.2012 № 499, який містить Розділ VII «Сільський (зелений) туризм»). Розглянемо стан розвитку сіль- 
ського туризму в Україні, на основі даних, зібраних із використанням вищезазначеної форми, шляхом їх узагальнення в табл. 1.

За результатами проведених аналітичних досліджень було виявлено, що спостерігається активізація розвитку сільського туризму, про що свідчать показники кількості садиб, кількості розміщених осіб та рівня доходів. Пріоритетними є період літнього та зимового відпочинку, а також короткотривалий відпочинок, тур «вихідного дня».

У розрізі регіонів найбільша кількість садиб у 2017 р. була зосереджена в Івано-Франківській області - 306, або 81\%; 16, або 9\%, садиб від загальної кількості надають послуги в Чернівецькій області; 14, або 4\%, та 8 , або $2 \%$, садиб розташовані у Львівській та Закарпатській областях, а 4\% фізичних осіб - підприємців, які надають послуги сільського туризму, зареєстровані в усіх інших областях України [14]. Зведену інформацію про розподіл кількості садиб у регіонах України наведено на рис. 1.

Фактичну кількість садиб сільського туризму, які приймають туристів, визначити дуже важко, оскільки основна їх частина (за різними оцінками, до 80-90\%) перебуває «у тіні», тобто $є$ незареєстрованою. Наприклад, лише на сайті Karpaty.Info через пошук садиб турист може ознайомитися з 2294 садибами, що значно перевищує офіційні дані [10]. Згідно з офіційною статистикою, сільські садиби у певних областях, зокрема Запорізькій, Житомирській, Київській, Харківській та Херсонській, відсутні. Проте у цих же областях, за даними ГО «Спілка сільського зеленого туризму», кількість садиб, які працюють у даних регіонах та пройшли категоризацію знаком «Українська гостинна садиба», становить 19 садиб [23].

Статистичні дані про сільський зелений туризм та обсяги туристів, які скористалися послугами садиб у 2017 р., підтверджують думку про те, що осередки функціонування та розвитку такого виду підприємницької діяльності перш за все залежать від природних умов. Так, дві садиби Волинської області надали послуги 3050 туристам, а дві садиби Кірово- градської області відвідало вдвічі менше туристів 1669 осіб [14]. Це пояснюється та підтверджується тим фактом, що на території Волинської області розташовані Шацькі озера, які є основним осередком для літнього відпочинку, що, своєю чергою, сприяє розвитку підприємництва у сфері сільського зеленого туризму.

Ураховуючи можливості розвитку сільського туризму, місцеві, сільські та селищні ради об'єднаних територіальних громад (ОТГ) у стратегію розвитку ОТГ включають сільський туризм як один із пріоритетних напрямів.

В Україні до складу ОТГ увійшли понад 4 тис колишніх місцевих рад, на території яких проживає 9 млн людей. Такі темпи міжмуніципальної консолідації міжнародні експерти називають дуже високими [11]. Житомирський регіон займає перше місце в Україні в загальному рейтингу спроможності громад. На Житомирщини сформовано 56 ОТГ [11]. Вона входить у п'ятірку найбільших за площею областей України. Завдяки вигідному географічному положенню i розгалуженій мережі автомобільних шляхів та залізниць область має зручне транспортне сполучення, а достатній рівень розвитку транспортної інфраструктури формує потенціал для розвитку в'їзного і внутрішнього туризму.

Чисельність населення Житомирської області на 01.01.2019 становила 1 млн 220 тис осіб, у тому числі 721,4 тис, або 59\%, міського населення та 498,8 тис, або 41\%, сільського населення [18]. 82,6\% населення проживає в ОТГ [11]. Житомирщина має потужний ресурсний потенціал для розвитку туризму, починаючи від природних об'єктів, аналогів яким немає в Україні та світі, а саме Геологічний заказник «Камінне

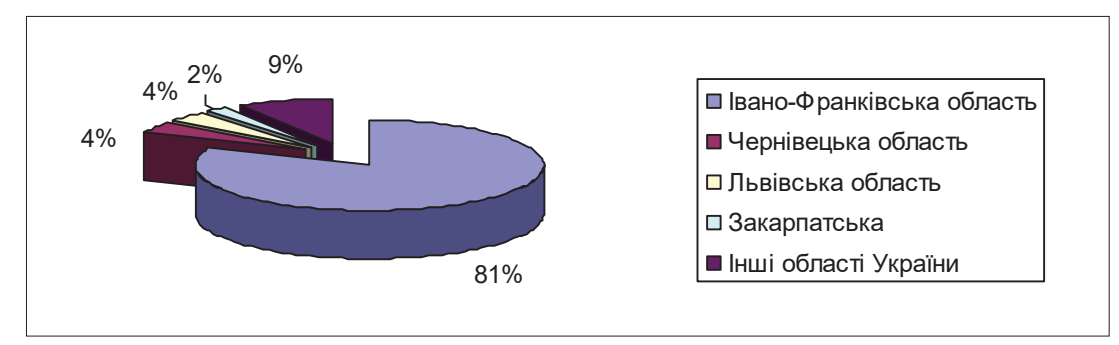

Рис. 1. Частка садиб сільського туризму за областями України, \% Джерело: сформовано на основі [14]

Таблиця 1

Характеристика стану розвитку сільського туризму в Україні

\begin{tabular}{|l|c|c|c|c|c|}
\hline \multirow{2}{*}{$\begin{array}{c}\text { Найменування } \\
\text { показника }\end{array}$} & \multicolumn{3}{|c|}{ Роки } & \multicolumn{2}{c|}{ Відхилення 2017 р./2015 р. } \\
\cline { 2 - 6 } & $\mathbf{2 0 1 5}$ & $\mathbf{2 0 1 6}$ & $\mathbf{2 0 1 7}$ & $+/-$ & \% \\
\hline Кількість садиб, од. & 235 & 375 & 377 & +142 & $+60,4$ \\
\hline Кількість розміщених осіб, ос. & 49253 & 79891 & 82570 & +33317 & $+67,6$ \\
\hline Доходи від наданих послуг, тис грн & 18369,0 & 41879,5 & 53594,4 & $+35225,4$ & $3 б$. в 3 р. \\
\hline Витрати від наданих послуг, тис грн & 10186,9 & 25052,8 & - & - & - \\
\hline Питома вага витрат у доходах, \% & 55,5 & 59,8 & - & - & X \\
\hline Кількість ночівель, од. & 106233 & 200709 & 2013061 & +1906828 & 36. в 19 p. \\
\hline Середня тривалість перебування, днів & 2,2 & 2,5 & 2,6 & $+0,4$ & $+18,2$ \\
\hline Коефіціснт використання місткості, \% & 0,19 & 0,16 & 0,20 & 0,01 & $\mathrm{X}$ \\
\hline
\end{tabular}

Джерело: сформовано на основі [14] 
село», більш як 500-літні дуби «Урочища «Тригір'я», унікальні сосни «Урочища «Модрина», реліктова Азалія Понтійська Поліського природного заповідника і закінчуючи великим різноманіттям сіл із самобутньою культурою.

Які ж виконавчі органи та як регіональна влада в умовах децентралізації регулює розвиток сільського туризму на Житомирщині?

У Житомирській облдержадміністрації діє Управління культури та туризму, до завдань якого, зокрема, належить аналіз стану та тенденцій культурного, туристичного розвитку в межах області та вжиття заходів щодо усунення недоліків; забезпечення реалізації державної політики у сфері культури, туризму, охорони культурної спадщини, а також державної мовної політики на відповідній території; сприяння загальнонаціональній культурній консолідації суспільства, формуванню цілісного культурно-інформаційного простору, захисту та просуванню високоякісного різноманітного національного культурного та туристичного продукту; забезпечення захисту прав творчих працівників та їхніх спілок, соціального захисту працівників підприємств, установ та організацій у сфері культури, туризму та охорони культурної спадщини тощо. Для виконання вищеперерахованих завдань у межах Управління діє відділ охорони культурної спадщини та туризму.

Управлінню культури та туризму підпорядковуються районні відділи/сектори культури та туризму райдержадміністрацій або ОТГ.

В області активно працює Житомирський відокремлений підрозділ установи «Центр розвитку місцевого самоврядування», метою діяльності якого є зміцнення діяльності місцевих органів влади в умовах децентралізації, у тому числі шляхом сприяння розвитку туризму.

Суттєву роль у популяризації туризму в регіоні відіграє КП «Житомирський обласний туристичний інформаційний центр» (ЖОТІЦ) [12]. ЖОТІЦ працює безпосередньо для сприяння та реалізації туристичного потенціалу Житомирщини й $є$ основною з'язуючою ланкою між усіма групами інтересів: учасниками туристичної інфраструктури, обласною владою, громадою та відвідувачами міста.

Основними завданнями ЖОТІЦ $є$ сприяння розвитку туристичного потенціалу області та міста, налагодження якісних та ефективних комунікацій, створення умов та поліпшення позицій Житомирщини як туристичної області через розвиток та просування привабливих туристичних продуктів і послуг, а також формування позитивних туристичних вражень. У туристичному інформаційному центрі можливо безкоштовно отримати детальну інформацію про туристичну інфраструктуру, архітектурну та культурну спадщину, екскурсійні маршрути та можливості дозвілля в Поліському краї, зокрема з використанням послуг сільських садиб [12].

Розглянемо діяльність існуючих сільських садиб за даними Житомирського обласного туристично-інформаційного центру в табл. 2.
Переваги розвитку сільського туризму для Житомирщини очевидні, оскільки розвиток туризму значно збільшить доходи селян, що поліпшить економічний розвиток сіл, збільшить зайнятість сільського населення, приїзд туристів покращить збереження не тільки пам'яток, а й довкілля, а також створюватимуться нові робочі місця. Однак слід ретельно підходити до створення сільських садиб, оскільки не всі сільські місцевості підходять для розвитку сільського зеленого туризму.

Узагальнимо можливості та загрози, сильні та слабкі сторони розвитку сільського туризму в Житомирській області в табл. 3.

Ураховуючи результати аналізу, стратегічними цілям розвитку сільського туризму на Житомирщині можна визначити такі:

1) підтримка, розвиток і використання історичної спадщини на території ОТГ Житомирщини. Успішним туристичним «магнітом» можуть стати маєтки XIX ст., які знаходяться на територіях сільських поселень та невеликих міст, наприклад у селі Червоне Червоненської ОТГ розташований величний палац шляхтича Грохольського. На території палацу збереглося безліч готичних деталей, красиві вежі і фонтан із чавуну. Усе це залишає незабутнє враження від перебування у старовинній будівлі. Сам палац побудований у стилі неоготики та істотно виділяється на фоні інших будівель цієї місцевості. Інший палац у селі Андрушівка був однією із садиб Миколи Терещенка. Побудований у 1848 р. у стилі французького неоренесансу, розташований у центрі села посеред старовинного парку з напрочуд гарним лебединим ставком. Інший відомий маєток - маєток Евеліни Ганської (дружини Оноре де Бальзака) - знаходиться в селі Верхівня Ружинського району Житомирської області. Окремі маєтки Житомирщини були частково відреставровані і продовжують функціонувати як туристичні атракції. У деяких із них розташовано музеї, виставки, проводяться фестивалі та інші культурно-мистецькі заходи, які сприяють підвищенню рівня знань з історії, а також зростанню туристичного потоку в ці місця.

Основною проблемою пам'яток $є$ те, що вони потребують відновлення, а на це потрібні кошти. Можливо, в умовах децентралізації місцеві органи державної влади на основі європейського досвіду зможуть позитивно вирішити питання туристичного використання старовинних маєтків. Розміщення сільських садиб навколо таких туристичних «магнітів», як палаци та маєтки, може забезпечити їхніх власників цілорічним потоком туристів;

2) популяризація маловідомих туристичних місць сільського туризму, яка передбачала б наявність транспортного сполучення, садиб сільського туризму у визначених туристичних місцях, сприяння проведенню фестивалів, конкурсів; дуже доцільним було б створення туристичних марок сіл чи територіальних громад, наприклад с. Немиринці Ружинського району 
Таблиця 2

Перелік туристичних послуг сільських садиб Житомирщини

\begin{tabular}{|c|c|c|}
\hline Район/ОТГ & Назва садиби & Види послуг сільського туризму \\
\hline \multirow{2}{*}{$\begin{array}{l}\text { Коростишівський/ } \\
\text { Коростишівська } \\
\text { міська ОТГ }\end{array}$} & $\begin{array}{l}\text { Культурно-мистецький } \\
\text { центр «Поліська хата» }\end{array}$ & \multirow[b]{2}{*}{$\begin{array}{l}\text { - театралізовані народні свята та вечорниці в автентичному оформленні; } \\
\text { - майстер-класи з різних видів декоративно-прикладного мистецтва } \\
\text { (писанкарство, вишивка, розпис по склу, художня обробка шкіри, } \\
\text { декоративний розпис, витинанка тощо); } \\
\text { - пленери для художників, учнів та студентів художніх навчальних } \\
\text { закладів; } \\
\text { - проведення дитячих спортивно-мистецьких та вишкільних козацьких } \\
\text { таборів; } \\
\text { - господарські школи (семінари з екобудівництва, органічного } \\
\text { землеробства, альтернативних джерел енергії, травництва тощо); } \\
\text { - майстер-класи з оздоровчого харчування (випікання хліба на заквасці, } \\
\text { виготовлення корисних солодощів тощо) }\end{array}$} \\
\hline & $\begin{array}{l}\text { Екопростір «Тетерівський } \\
\text { Кіш» }\end{array}$ & \\
\hline $\begin{array}{l}\text { Хорошівський/ } \\
\text { Новоборівська ОТГ }\end{array}$ & Садиба «Лідія» & $\begin{array}{l}\text { - екскурсії для дітей, молоді, дорослих місцевістю, цікавою } \\
\text { історичними, екологічними та геологічними пам’ятками; } \\
\text { - біля села можна побачити Кропивенські кургани Х-ХІІІ ст., колонії } \\
\text { сірих чапель, гори-громуші, у річці водиться близько } 120 \text { видів риб } \\
\text { (рибалка); } \\
\text { - домашня сільська кухня }\end{array}$ \\
\hline $\begin{array}{l}\text { Любарський/ } \\
\text { Любарська селищна } \\
\text { ОТГ }\end{array}$ & Садиба «Над Случчю» & $\begin{array}{l}\text { - послуги лікаря народної й нетрадиційної медицини, де можна } \\
\text { проконсультуватися або продіагностуватися, а також пройти сеанси } \\
\text { мануальної терапії, фармакопунктури, краніосакральної терапії, } \\
\text { біоенерго-інформотерапії тощо; } \\
\text { - органічні продукти, домашня кухня }\end{array}$ \\
\hline $\begin{array}{l}\text { Брусилівський/ } \\
\text { Брусилівська селищна } \\
\text { ОТГ }\end{array}$ & Садиба «Володимирська» & $\begin{array}{l}\text { - значна кількість різноманітних птахів і тварин (коні, вівці, кролі, кури, } \\
\text { голуби) подарує радість відвідувачам садиби; } \\
\text { - проживання, харчування, лазня, барбекю, уроки верхової їзди, катання } \\
\text { на конях, квадроциклах, екскурсії у розплідник німецької вівчарки }\end{array}$ \\
\hline \multirow[t]{2}{*}{ Бердичівський } & Садиба «Сила» & \multirow{2}{*}{$\begin{array}{l}\text { - проведення фольклорних свят календарного циклу, обрядів і вікових } \\
\text { посвят; } \\
\text { - кулінарні тури (фірмові страви з баранини в «Карпатському селі»); } \\
\text { - катання на квадроциклі, на конях верхи, на возі, на санях, стрільба з } \\
\text { лука, арбалета, риболовля, походи за грибами і ягодами; } \\
\text { - екскурсії до міста Бердичева }\end{array}$} \\
\hline & Садиба «Карпатське село» & \\
\hline Малинський & Садиба «Полісся» & $\begin{array}{l}\text { - організація різноманітних свят; } \\
\text { - корпоративний відпочинок; } \\
\text { - кінна прогулянка, харчування із сім'єю та участь у майстер-класах } \\
\text { тощо }\end{array}$ \\
\hline \multirow{2}{*}{$\begin{array}{l}\text { Новоград-Волинський/ } \\
\text { Новоград-Волинська } \\
\text { міська ОТГ }\end{array}$} & $\begin{array}{l}\text { Поселення родових маєтків } \\
\text { в урочищі Тартак }\end{array}$ & \multirow{2}{*}{$\begin{array}{l}\text { - групові екскурсії для ознайомлення з побутом та методами } \\
\text { господарювання в садибах, органічним городництвом, будівництвом } \\
\text { глиносолом’яних будівель; } \\
\text { - проведення семінарів і майстер-класів із народних ремесел } \\
\text { («Писанкарство», «Вирізання ложок», «Лялька-мотанка» тощо); } \\
\text { - проживання в наметах на території екопоселення тощо }\end{array}$} \\
\hline & $\begin{array}{l}\text { Екологічне поселення } \\
\text { «Простір Любові» }\end{array}$ & \\
\hline
\end{tabular}

Джерело: узагальнено автором на основі [12; 13$]$

Житомирської області традиційно проводить фестиваль «Купальські роси»;

3) забезпечення екологічної стабільності, поліпшення якості та привабливості природних ресурсів. Наявність значного потенціалу для розвитку сільського зеленого туризму вимагає комплексного підходу й до вирішення екологічних проблем. Україна, яка володіє близько $1 \%$ світового запасу сільськогосподарських земель, утрачає щороку від 0,6 до 1 т гумусу з одного гектара, що зумовлено екстенсивними методами землеробства. Одним із важливих складників екологічного розвитку сільського туризму є захист біологічного різноманіття, яке зосереджене у національних природних парках. У Житомирській області незначна частина сільських садиб, які займаються зеленим туризмом, територіально знаходяться в межах заповідників наці- онального або місцевого значення. Оскільки Україна орієнтується на сталий розвиток, за якого велика увага звертається на захист та охорону довкілля, то Поліський та Древлянський національні природні парки могли би стати центрами сталого розвитку та поширювати ці ідеї серед населення.

Розроблення стратегії розвитку сільського туризму 3 обов'язковим включенням екологічного складника під час споживання туристичного продукту допомогло б вирішити екологічні проблеми, а для туристичної галузі регіону чи окремої територіальної громади створити потужний напрям спеціалізації;

4) забезпечення зростання туристичного потоку, залучення нових споживачів шляхом упровадження соціального туризму. Відомо, що цільовою аудиторією сільського туризму є мешканці великих міст (понад 100 тис 
SWOT-аналіз розвитку сільського туризму Житомирщини

\begin{tabular}{|c|c|}
\hline Сильні сторони & Слабкі сторони \\
\hline $\begin{array}{l}\text { 1. Значна кількість історико-культурних та природних } \\
\text { ресурсів. } \\
\text { 2. Розвинута мережа заповідних територій. } \\
\text { 3. Вигідне економіко-географічне розташування. } \\
\text { 4. Розвиненість транскордонної інфраструктури, наявність } \\
\text { єврорегіону. } \\
\text { 5. Достатня кількість садиб у регіоні. } \\
\text { 6. Розвиток готельної інфраструктури. } \\
\text { 7. Розвиток подієвого туризму в регіоні. } \\
\text { 8. Підготовка якісних професійних кадрів у галузі туризму. } \\
\text { 9. Функціонування системи навчальних закладів, які } \\
\text { здійснюють підготовку фахівців туристичної галузі за різними } \\
\text { напрямами. } \\
\text { 10. Наявність міжнародних зв’язків. } \\
\text { 11. Популяризація національної кухні. } \\
\text { 12. Розвинута мережа закладів швидкого харчування. } \\
\text { 13. Значна частка сільського населення у загальній структурі } \\
\text { населення регіону. } \\
\text { 14. Ефективне організаційне, методичне та інформаційно- } \\
\text { правове забезпечення розвитку сільського туризму. }\end{array}$ & $\begin{array}{l}\text { 1. Зменшення обсягів фінансування туристичної галузі. } \\
\text { 2. Незадовільний стан автомобільних доріг. } \\
\text { 3. Відсутність чіткої стратегії розвитку сільського зеленого } \\
\text { туризму в регіоні. } \\
\text { 4. Посилення неврегульованості нормативно-правових питань } \\
\text { надання послуг. } \\
\text { 5. Низький рівень якості туристичного та рекреаційного } \\
\text { обслуговування. } \\
\text { 6. Посилення природних катаклізмів у результаті зменшення } \\
\text { лісистості, деградації грунтів, недостатності опадів, пожеж, } \\
\text { забруднення водних об'єктів. } \\
\text { 7. Невідповідність високого рівня ціни низькому рівню якості } \\
\text { послуг. } \\
\text { 8. Зубожіння населення, потенційних туристів. } \\
\text { 9. Недостатність кваліфікованих кадрів туристичної галузі в } \\
\text { ОТГ. } \\
\text { 10. Низький рівень взаємодії туристичного бізнесу, влади та } \\
\text { науки. } \\
\text { 11. Відсутність досвіду діяльності у сфері сільського зеленого } \\
\text { туризму в сільській місцевості. } \\
\text { 12. Недостатній рівень просування сільських садиб із } \\
\text { використанням Інтернету. }\end{array}$ \\
\hline Можливості & Загрози \\
\hline $\begin{array}{l}\text { 1. Використання Інтернет-ресурсів для рекламування, } \\
\text { бронювання та інформування про послуги садиби. } \\
\text { 2. Організація тренінгів туристичного спрямування. } \\
\text { 3. Підтримка сільських садиб шляхом формування мережі } \\
\text { ТІЦ окремих ОТГ. } \\
\text { 4. Створення нових зелених маршрутів. } \\
\text { 5. Створення віртуальних 3D-турів. } \\
\text { 6. Підвищення рівня раціональності використання } \\
\text { туристичних ресурсів шляхом їх паспортизації. } \\
\text { 7. Розроблення програми оптимізації транспортних потоків } \\
\text { із метою підвищення доступності до віддалених регіонів } \\
\text { області. } \\
\text { 8. Підвищення рівня інвестиційної привабливості } \\
\text { туристичних регіонів шляхом створення програми } \\
\text { формування туристичної репутації (бренду) регіону. } \\
\text { 9. Підвищення якості туристичних послуг шляхом } \\
\text { сертифікації та категоризації. } \\
\text { 10. Популяризація органічної продукції сільського туризму. } \\
\text { 11. Збільшення кількості міжнародних туристичних проектів } \\
\text { розвитку сільського зеленого туризму. }\end{array}$ & $\begin{array}{l}\text { 1. Складна економічна ситуація в країні. } \\
\text { 2. Незначна кількість розроблених туристичних маршрутів у } \\
\text { регіоні. } \\
\text { 3. Незначний асортимент продукції сільського зеленого } \\
\text { туризму в регіоні. } \\
\text { 4. Незадовільний рівень інформаційно- рекламного } \\
\text { забезпечення туризму в регіоні. } \\
\text { 5. Швидкий розвиток конкуруючих країн-сусідів (Польща, } \\
\text { Білорусь) та регіонів (Київщина, Рівненщина, Хмельниччина). } \\
\text { 6. Відсутність професійного досвіду господаря, персоналу } \\
\text { садиби. } \\
\text { 7. Поширення явища банкрутства туристичних організацій } \\
\text { регіону. } \\
\text { 8. Значна частка неорганізованого туризму у загальній } \\
\text { структурі туристичних послуг. } \\
\text { 9. Погане знання (незнання) мов господарем та персоналом } \\
\text { садиби. } \\
\text { 10. Відсутність єдиної системи туристичного маркування } \\
\text { рекреаційних територій регіону. } \\
\text { 11. Незацікавленість мешканців сільських територій у } \\
\text { навчанні та отриманні нового досвіду і знань. } \\
\text { 12. Зубожіння сільських територій та зменшення чисельності } \\
\text { населення сіл. }\end{array}$ \\
\hline
\end{tabular}

Джерело: узагальнено автором

населення) та урбанізованих територій. До парадигми соціального туризму відносимо участь органів державної влади у розвитку туризму; надання субсидій на туристичну подорож окремим соціально вразливим категоріям населення; широке охоплення туристичним відпочинком громадян України. Крім того, великі перспективи $є$ у залученні іноземних туристів до споживання продукту сільського туризму Житомирської області. Перспективною цільовою групою є канадські та китайські туристи, а також невеликі туристичні групи із Франції, Чехії, Німеччини, Ізраїлю, які мають етнічні корені на Житомирщині. Це величезний ринок. Рекламна кампанія могла б залучити цей потенціал споживачів, особливо якщо зробити акценти на екологічному складнику.
Висновки. Розвиток сільського туризму має велике значення як для об'єднаної територіальної громади, так і для туристів. Для територіального розвитку сільський туризм дає можливість отримати додатковий дохід, поліпшити інфраструктуру теритоpiï, зберегти історико-культурну спадщину, забезпечує особистий розвиток сільського населення. Розуміння важливості розвитку сільського туризму є й на державному рівні. Зокрема, 2020 р. визнано Національною туристичною організацією роком розвитку туризму в регіонах та сільських територіях [17]. Під час формування стратегічних цілей в умовах децентразації важливо враховувати відповідність стратегічних цілей із питань туризму ОТГ Стратегії розвитку 
Житомирської області та Стратегії розвитку туризму та курортів України.

Для успішного розвитку сільського туризму на Житомирщині організовано низку стимулюючих заходів щодо формування туристичного іміджу регіону шляхом виділення притаманних спеціалізованих рис продукту сільського туризму, представлення області на різноманітних туристичних ярмарках та інших заходах, які дають можливість створити інформаційний ажіотаж. Перспективним $є$ формування мережі туристично-інформаційних центрів в ОТГ. Варто зазначити роль Житомирського обласного туристично-інформаційного центру у популяризації сільського туризму серед потенційних туристів з інших регіонів.

Умовою ефективного розвитку сільського туризму $€$ залучення зовнішніх інвестицій із метою реалізації стратегії розвитку сільського туризму, а також через удосконалення та розвиток інфраструктури і матеріально-технічної бази сільського туризму. Суттеву роботу в даному напрямі проводить Житомирський відокремлений підрозділ Центру місцевого самоврядування, проводячи навчання та сприяючи залученню інвестицій у регіон. У межах Центру місцевого самоврядування у власників садиб є можливість пройти навчання зі створення туристичних продуктів, нових маршрутів, а також паспортизації туристичних ресурсів, що дасть змогу в перспективі диверсифікувати діяльність у сфері сільського туризму.

Важливими чинниками розвитку сільського туризму є підвищення якості туристичного продукту та якості обслуговування на основі європейських норм та екологічних параметрів, а також організація прес-турів сільськими садибами, яка дає можливість із рекламною метою оцінити переваги продукту сільського туризму, котрий пропонується господарями сільських садиб регіону. Житомирщина має позитивний досвід роботи відокремленого підрозділу ГО «Спілка сприяння розвитку сільського зеленого туризму в Україні», що виконує важливі завдання підвищення якості сільського туризму в регіоні.

Таким чином, співпраця власників садиб з усіма зацікавленими сторонами у розвитку сільського туризму дає змогу ефективно розвивати сільський туризм на Житомирщині.

\section{Список літератури:}

1. Биркович В.І. Удосконалення державного регулювання розвитку туризму на регіональному рівні. Стратегічні nрiоритети. 2007. № 4(5). С. 157-163.

2. Голиков А.П., Казакова Н.А. Стратегия регионального развития: европейский контекст : монография. Харьков : Екограф, 2008. 180 с.

3. Голод А., Коркуна О. Інституційне середовище туристичного та готельно-ресторанного бізнесу в Україні в умовах децентралізації. Європейський журнал економіки та менеджменту. 2019. № 5(4). С. $78-85$.

4. Гончарук Н., Колєда Г. Система управління сферою туризму в умовах децентралізації влади в Україні. Державне управління та місиеве самоврядування. 2018. Вип. 4(39). C. 95-103. URL : http://www.dridu.dp.ua/ vidavnictvo/2018/2018 04(39)/16.pdf (дата звернення: 12.05.2020).

5. Закон України «Про особисте селянське господарство» № 742-IV від 15 травня 2003 p. URL : https://zakon.rada.gov.ua/laws/show/742-15 (дата звернення: 12.05.2020).

6. Закон України «Про туризм» № 324/95-ВР від 15 вересня 1995 p. URL : https://zakon.rada.gov.ua/laws/ show/324/95-\%D0\%B2\%D1\%80 (дата звернення: 12.05.2020).

7. Захарова С.Г. Роль органів місцевого самоврядування в розвитку індустрії туризму. Держава та регіони. 2008. № 4. C. 119-125.

8. Івашина Л. Роль об'єднаних територіальних громаду розвитку сільського зеленого туризму.Державне управління тамісиеве самоврядування.2017. Вип.3(34).C.143-148.URL:http://www.dridu.dp.ua/vidavnictvo/2017/2017_03(34)/22. pdf (дата звернення: 12.05.2020).

9. Ільїна М.В., Шпильовий I.М. Децентралізація управління сільськими територіями та їі вплив на розвиток туризму. Економіка і суспільство. 2016. № 2. C. 446-451. URL : http://www.economyandsociety.in.ua/journal/2_ukr/80. pdf (дата звернення: 12.05.2020).

10. Інформаційний ресурс KarpatyInfo. Відпочинок в Карпатах. URL : https://www.karpaty.info/ua/ (дата звернення: 12.05.2020).

11. Інформаційний ресурс з реформи децентралізації. URL : https://decentralization.gov.ua/areas (дата звернення: 12.05.2020).

12. Інформаційний ресурс КП «Житомирський обласний туристично-інформаційний центр». URL : http://tic.zt.ua/ (дата звернення: 12.05.2020).

13. Каталог садиб сільського зеленого туризму Житомирщини. Житомир : Полісся, 2014. 18 с.

14. Колективні засоби розміщування в Україні. Статистичний бюлетень 2014 р., 2015 р., 2016 р. та 2017 р. / Державна служба статистики України. URL : http://www.ukrstat.gov.ua/ (дата звернення: 12.05.2020).

15. Костриця М.М. Сільський туризм: теорія, методологія, практика : монографія / за наук. кер. і ред. проф. Є.І. Ходаківського, проф. Ю.С. Цал-Цалка. Житомир : ЖДТУ, 2006. 196 с.

16. Матвійчук Л.Ю., Тищук І.В. Сільський зелений туризм як фактор регіонального розвитку: методологічний аспект та практичний досвід : монографія. Луцьк : ЛНТУ, 2017. 260 с.

17. Національна туристична організація України. 2020 - рік розвитку туризму в регіонах та сільських територіях. URL : http://www.ntoukraine.org/ntoukriane_2020_ua.html (дата звернення: 12.05.2020). 
18. Офіційний сайт Державної служби статистики України. URL : http://www.ukrstat.gov.ua/ (дата звернення: 12.05.2020).

19. Постанова КМУ «Про затвердження порядку надання послуг з тимчасового розміщення (проживання)» від 15 березня 2006 р. № 297. URL : https://zakon.rada.gov.ua/laws/show/297-2006-\%D0\%BF (дата звернення: 12.05.2020).

20. Про місцеве самоврядування в Україні : Закон України від 6 листоп. 1998 р. № 280/ 97-ВР. Biдомості Верховної Ради Украӥни. 1997. № 24. Ст. 170.

21. Проєкт закону України «Про сільський зелений туризм». URL : http://w1.c1.rada.gov.ua/pls/zweb2/webproc4_2? pf3516=4299\&skl=5 (дата звернення: 12.05.2020).

22. Проєкт закону України «Про аграрний туризм та агротуристичну діяльність» URL : http://ruraltourism.com. ua/?a=viewmaterial\&id=9 (дата звернення: 12.05.2020).

23. Спілка сприяння розвитку сільського зеленого туризму в Україні URL : http://www.greentour.com.ua (дата звернення: 12.05.2020).

\section{References:}

1. Byrkovych V.I. (2007) Udoskonalennja derzhavnogo reguljuvannja rozvytku turyzmu na regional'nomu rivni [Improvement of the state regulation of tourism development on regional level]. Strategichni priorytety [Strategically Priorities], vol. 4(5), pp. 157-163.

2. Golikov A.P., Kazakova N.A. (2008) Strategiya regional'nogo razvitiya: evropeyskiy kontekst: monografiya [Strategy of European development: regional context: monograph]. Khar'kov: Ekograf, 180 p. (in Russian)

3. Golod A., Korkuna O. (2019) Instytucijne seredovyshhe turystychnogo ta gotel'no-restorannogo biznesu v Ukrai'ni v umovah decentralizacii' [Institutional environment of tourism and hotel, restaurant businesses in Ukraine in decentralization framework]. Jevropejs 'kyj zhurnal ekonomiky ta menedzhmentu [European journal of economics and management], vol. 5(4), pp. $78-85$.

4. Goncharuk N., Koljeda G. (2018) Systema upravlinnja sferoju turyzmu v umovah decentralizacii' vlady v Ukrai'ni [System of management in tourism field within decentralization framework in Ukraine]. Derzhavne upravlinnja ta misceve samovrjaduvannja [Public administration and local self-government], vol. 4(39), pp. 95-103. Available at: http://www.dridu.dp.ua/vidavnictvo/2018/2018_04(39)/16.pdf (accessed 12 May 2020).

5. Zakon Ukrai'ny «Pro osobyste seljans'ke gospodarstvo» [Law of Ukraine «About personal peasant economy»] № 742-IV, $15^{\text {th }}$ May 2003. Available at: https://zakon.rada.gov.ua/laws/show/742-15(accessed 12 May 2020).

6. Zakon Ukrai'ny «Pro turyzm» [Law of Ukraine «About Tourism»]. № 324/95-VR, $15^{\text {th }}$ September 1995. Available at: https://zakon.rada.gov.ua/laws/show/324/95-\%D0\%B2\%D1\%80 (accessed 12 May 2020).

7. Zaharova S.G. (2008) Rol' organiv miscevogo samovrjaduvannja v rozvytku industrii' turyzmu [The role of local governments in the development of the tourism industry.]. Derzhava ta regiony [State and regions], vol. 4, pp. 119-125.

8. Ivashyna L. (2017) Rol' ob'jednanyh terytorial'nyh gromad u rozvytku sil's'kogo zelenogo turyzmu [The role of united territorial communities in the development of rural green tourism]. Derzhavne upravlinnja ta misceve samovrjaduvannja [Public administration and local self-government], vol. 3(34), pp. 143-148. Available at: http://www.dridu.dp.ua/ vidavnictvo/2017/2017_03(34)/22.pdf (accessed 12 May 2020).

9. Il'i'na M.V, Shpyl'ovyj I.M. (2016) Decentralizacija upravlinnja sil's'kymy terytorijamy ta i'i' vplyv na rozvytok turyzmu [Decentralization of rural management and its impact on tourism development]. Ekonomika $i$ suspil'stvo [Economy and society], vol. 2, pp. 446-451. Available at: http://www.economyandsociety.in.ua/journal/2_ukr/80.pdf (accessed 12 May 2020).

10. Information resource KarpatyInfo. Rest in the Carpathians. Available at: https://www.karpaty.info/ua/ (accessed 12 May 2020).

11. Information resource on decentralization reform. Available at: https://decentralization.gov.ua/areas (accessed 12 May 2020).

12. Information resource of Zhytomyr Regional Tourist Information Center. Available at: http://tic.zt.ua/ (accessed 12 May 2020).

13. Katalog sadyb sil's'kogo zelenogo turyzmu Zhytomyrshhyny (2014) [Catalog of farmsteads of rural green tourism of Zhytomyr region]. Vydavnyctvo «Polissja». $18 \mathrm{p}$.

14. Kolektyvni zasoby rozmishhuvannja v Ukrai'ni. Statystychnyj bjuleten' [Collective accommodation facilities in Ukraine. Statistical bulletin] (2014, 2015, 2016, 2017). Derzhavna sluzhba statystyky Ukrai'ny. Available at: http://www.ukrstat.gov.ua/ (accessed 12 May 2020).

15. Kostrycja M.M. (2006) Sil's'kyj turyzm: teorija, metodologija, praktyka: monografija [Rural tourism: theory, methodology, practice: monograph]/ za nauk. kerivnyctvom i red. prof. Je.I. Hodakivs'kogo, prof. Ju.S. Cal-Calko. Zhytomyr: ZhDTU. 196 p. (in Ukrainian)

16. Matvijchuk L.Ju., Tyshhuk I.V. (2017) Sil's'kyj zelenyj turyzm jak faktor regional'nogo rozvytku: metodologichnyj aspekt ta praktychnyj dosvid: monografija [Rural green tourism as a factor of regional development: methodological aspect and practical experience: monograph]. Luc'k: RVV Luc'kogo NTU. 260 p. (in Ukrainian)

17. National Tourist Organization of Ukraine. 2020 is the year of tourism development in the regions and rural areas. Available at: http://www.ntoukraine.org/ntoukriane_2020_en.html (accessed 12 May 2020).

18. Official site of the State Statistics Service of Ukraine. Available at: http://www.ukrstat.gov.ua/ (accessed 12 May 2020). 
19. Postanova KMU «Pro zatverdzhennja porjadku nadannja poslug z tymchasovogo rozmishhennja (prozhyvannja)» [Resolution of the Cabinet of Ministers of Ukraine «On approval of the procedure for providing temporary accommodation services»]. 15 ${ }^{\text {th }}$ March 2006. № 297. Available at: https://zakon.rada.gov.ua/laws/show/297-2006-0D0\%BF (accessed 12 May 2020).

20. Pro misceve samovrjaduvannja v Ukrai'ni: Zakon Ukrai'ny [Law of Ukraine «On local self-government in Ukraine»]. $6^{\text {th }}$ November 1998. № 280/97-VR. Vidom. Verhovnoi'Rady Ukrai'ny. 1997. № 24, st. 170.

21. Proekt Zakonu «Pro sil's'kyj zelenyj turyzm» [Draft Law of Ukraine «On Rural Green Tourism»]. Available at: http://w1.c1.rada.gov.ua/pls/zweb2/webproc4_2?pf3516=4299\&skl=5 (accessed 12 May 2020).

22. Proekt Zakonu Ukrai'ny «Pro agrarnyj turyzm ta agroturystychnu dijal'nist'» [Draft Law of Ukraine «About agrarian tourism and agrotourism activity»]. Available at: http://ruraltourism.com.ua/?a=viewmaterial\&id=9 (accessed $12 \mathrm{May} 2020$ ).

23. Union for Promotion of Rural Green Tourism in Ukraine. Available at: http://www.greentour.com.ua (accessed 12 May 2020).

\section{РАЗВИТИЕ СЕЛЬСКОГО ТУРИЗМА В УСЛОВИЯХ ДЕЦЕНТРАЛИЗАЦИИ: ОПЫТ ЖИТОМИРЩИНЫ}

В статье рассмотрена сущзность сельского туризма, определены законодательные особенности организации сельского туризма в пределах объединенных территориальных общин. Обобщено влияние сельского туризма на развитие объединенной территориальной общины в условиях децентрализации. Проанализировань статистические данные состояния развития сельского туризма в разрезе регионов и Украины в иелом. Исследована Житомирская область как отдельный регион для развития сельского туризма, перечислень услуги сельских усадеб области. Определены государственные структуры, которые способствуют развитию туризма на региональном уровне. Проведен SWOT-анализ сельского туризма Житомирской области и определены стратегические цели его развития. Перечислены заинтересованные стороны в развитии сельского туризма и определена роль их сотрудничества в развитии туризма Житомирской области.

Ключевые слова: сельский туризм, сельская усадьба, децентрализация, объединенная территориальная община, сельский туризм Житомирщины.

\section{DEVELOPMENT OF RURAL TOURISM WITHIN DECENTRALIZATION REFORM IN UKRAINE: ZHYTOMYR REGION CASE-STUDY}

The purpose of the article is to study the state of the rural tourism on example of Zhytomyr region and to determine its role on regional communities' development by analyzing statistical data and forming relevant conclusions. Because of structural complexity of the tourism industry, the issue to study the impact of the rural tourism component on the development of village territorial communities is cut-edging. The article examines the essence of rural tourism, identifies the legislative aspects of the organization of rural tourism business within the united territorial communities. The influence of rural tourism on the development of united village territorial communities based on decentralization reform features is generalized. The research is based on the Ukrainian and regional statistical data of the number of village houses conducted rural tourism services. The case of Zhytomyr region as a separate region for the development of rural tourism business is studied; the services of rural estates of the region are listed. Zhytomyr region is one of the five largest regions of Ukraine. 56 united territorial communities were formed in the region. Due to the favorable geographical location and extensive network of roads and railways, the region has convenient transport links, and a sufficient level of transport infrastructure supports the development of inbound and domestic tourism. The main regional institutions that promote the development of tourism at the regional level have been identified. The SWOT-analysis of rural tourism of Zhytomyr region is carried out and the strategic goals of development are defined. The main strategic goals such as popularization of little-known tourist places of rural tourism; improvement of sustainability and attractiveness of natural resources; the growth of tourist flow through attracting new groups of consumers; support and development of historical heritage on the territory of Zhytomyr region were defined. As a conclusion, the list of stakeholders interested in rural tourism business is summarized and the role of their cooperation on the rural tourism development in Zhytomyr region is determined.

Key words: rural tourism, rural estate, decentralization, united territorial community, rural tourism in Zhytomyr region. 